\title{
Anna Maria Babbi, Il romanzo francese del Quattrocento: 'Pierre de Provence' e dintorni
}

\author{
Maria Colombo Timelli
}

\section{(2) OpenEdition}

10 Journals

\section{Édition électronique}

URL : http://journals.openedition.org/studifrancesi/32812

DOI : $10.4000 /$ studifrancesi.32812

ISSN : 2421-5856

Éditeur

Rosenberg \& Sellier

\section{Édition imprimée}

Date de publication : 1 décembre 2005

Pagination : 614-615

ISSN : 0039-2944

\section{Référence électronique}

Maria Colombo Timelli, « Anna Maria Babbi, I/ romanzo francese del Quattrocento: 'Pierre de Provence' e dintorni », Studi Francesi [En ligne], 147 (XLX | III) | 2005, mis en ligne le 30 novembre 2015, consulté le 19 avril 2021. URL : http://journals.openedition.org/studifrancesi/32812 ; DOI : https://doi.org/ 10.4000/studifrancesi.32812

Ce document a été généré automatiquement le 19 avril 2021.

\section{(c)}

Studi Francesi è distribuita con Licenza Creative Commons Attribuzione - Non commerciale - Non opere derivate 4.0 Internazionale. 


\title{
Anna Maria Babbi, Il romanzo francese del Quattrocento: 'Pierre de Provence' e dintorni
}

\author{
Maria Colombo Timelli
}

\section{RÉFÉRENCE}

ANNA MARIA BABBI, Il romanzo francese del Quattrocento: 'Pierre de Provence' e dintorni, «Critica del testo», VII/1, 2004, pp. 341-355.

1 Il s'agit d'une réflexion d'ensemble sur la tradition manuscrite des romans (originaux et remaniements en prose de textes en vers plus anciens) du $\mathrm{XV}^{\mathrm{e}}$ siècle. Anna Maria Babbi reprend des données déjà bien connues (par exemple sur la qualité modeste de ces manuscrits, qui contiennent normalement un seul texte: cf. Georges Doutrepont, Mises en prose, 1939; ou sur la production lilloise de l'atelier du 'Maistre de Wavrin': cf. Antoinette Naber, in «Revue du Nord», 1990), qu'elle enrichit par le résultat de ses propres recherches. Elle présente alors la tradition de Paris et Vienne (8 témoins, dont 2 seulement en parchemin, et 2 illustrés; édition par la même Babbi, Milano, 1992), puis celle de Pierre de Provence et la belle Maguelonne (édition Babbi, Soveria Mannelli, 2003). Pour celui-ci, le manuscrit aujourd'hui conservé à Coburg s'avère exceptionnel à plus d'un titre: c'est un ms. en parchemin, illustré, dont le texte est traduit en latin dans l'interligne, et est accompagné de gloses; cette copie servira par ailleurs de base pour la traduction en allemand (1527) et pour la circulation postérieure du roman en milieu germanophone. 